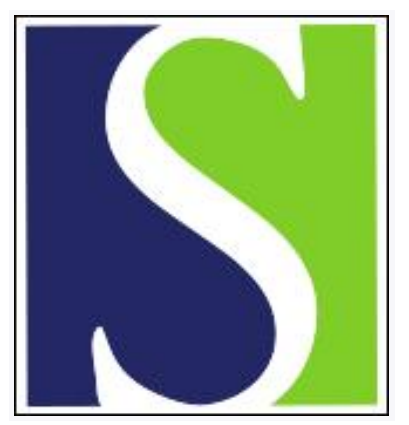

Scand J Work Environ Health 1991;17(4):240-247

https://doi.org/10.5271/sjweh.1707

Issue date: Aug 1991

\title{
Occupation and gastric cancer in Spain.
}

by Gonzalez CA, Sanz M, Marcos G, Pita S, Brullet E, Vida F, Agudo A, Hsieh CC

Affiliation: Unit of Epidemiology, Hospital of Mataro, Barcelona, Spain.

This article in PubMed: www.ncbi.nlm.nih.gov/pubmed/1925435

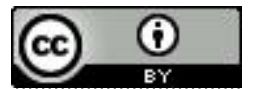




\title{
Occupation and gastric cancer in Spain
}

\author{
by Carlos A González, MPH, ${ }^{\dagger}$ Miguel Sanz, MD, ${ }^{2}$ Guillermo Marcos, MD, ${ }^{3}$ Salvador Pita, MPH, ${ }^{4}$ \\ Enric Brullet, MD, ${ }^{5}$ Francesc Vida, MD, ${ }^{6}$ Antonio Agudo, MD, ${ }^{1}$ Chung-Cheng Hsieh, $\mathrm{ScD}^{7}$
}

\begin{abstract}
GONZÁlEZ CA, SANZ M, MARCOS G, PITA S, BRULlET E, VIDA F, AGUDO A, HSIEH C-C. Occupation and gastric cancer in Spain. Scand J Work Environ Health 1991;17:240-7. The association between occupational exposure and stomach cancer was investigated in a multicenter case-referent study conducted in Spain on $\mathbf{3 5 4}$ histologically confirmed cases and 354 hospital referents, matched by age, gender, and residence. An increased risk of gastric cancer was found for coal mining workers [odds ratio (OR) 11.8], but the number of workers was small, and therefore the $95 \%$ confidence interval $(95 \%$ CI) was wide (95\% CI 1.36-103). An increased risk was observed for wood and furniture workers (OR 1.76), construction workers (OR 1.68), and glass and ceramic workers (OR 2.18), but none of these risks were statistically significant. According to an occupation-exposure linkage system an increased risk was found for occupations associated with exposure to silica and mineral dust (OR 1.80, $95 \% \mathrm{CI}$ 0.90-3.59). All of the OR estimates were adjusted for the confounding factors socioprofessional status and dietary habits. The possibility of a causal association between stomach cancer and coal and mineral dust is supported by the results.
\end{abstract}

Key terms: case-referent study, coal dust, mineral dust, occupation-exposure linkage system, stomach cancer.

Stomach cancer mortality and morbidity rates are decreasing in Spain, as well as in most of the developed countries. However, cancer incidence estimations for both genders (1) show that it was still the most frequent tumor in the world in 1980. In Spain, stomach cancer, in 1985, represented the second most frequent cancer in men and the third most frequent cancer in women (2).

Stomach cancer mortality is lowest in Spain in the Mediterranean area, whereas the highest mortality is found in the central regions of the Iberian Peninsula (Castilian Meseta), which is characterized by predominant farming activity and low industrial development (3).

The causes of stomach cancer have not yet been clearly delineated (4). However, there is strong evidence that diet could be one of the main causal factors (5). Several occupations have been identified as associated with gastric cancer. Results from studies in coal mining areas showed a consistent elevated risk of stomach cancer in coal miners in England (6) and the United States (7-9). Studies among rubber industry workers have

1 Unit of Epidemiology, Hospital of Mataró, Barcelona, Spain.

2 Department of Pathology, Hospital of Insalud, Soria, Spain.

3. Hospital Clinico, Zaragoza, Spain.

4 Provincial Delegation, Health and Consumer Council, La Coruña, Spain.

5 Department of Internal Medicine, Hospital of Sabadell, Sabadell, Spain.

6 Department of Internal Medicine, Hospital Center of Manresa, Manresa, Spain.

7 Department of Epidemiology, Harvard School of Public Health, Boston, Massachusetts, United States.

Reprint requests to Dr CA González, Unit of Epidemiology, Hospital de Mataró, S-08301 Mataró (Barcelona), Spain. shown a consistent excess of stomach cancer risk, although the association observed was generally weak (10-12). Several cohort studies on oil refinery workers have also shown a weak but consistent increase in stomach cancer risk (13-15).

Several studies have shown an increase in gastric cancer risk for occupations exposed to industrial dust. A case-referent study (16) showed an increase in risk for exposure to mineral dust. An increase in risk has been observed in historical cohort studies of workers exposed to cement dust (17), workers exposed to asbestos (18), and metal polishers (19). Two proportionate mortality studies have also shown an increase in risk for workers exposed to synthetic abrasives (20) and for metal polishers (21). Dust ingestion, therefore, could be considered an etiologic factor of gastric adenocarcinoma.

A cohort study carried out in Sweden showed an increased risk of stomach cancer for ethylene oxide production workers (22), although the number of cases was small and the results were not conclusive.

In this paper we present the results of a multicenter epidemiologic study on occupational exposure and stomach cancer risk in Spain. This study has also collected information on other exposures, such as present and past diet, medical history, smoking, and other life-style variables. The results for these variables will be reported separately.

\section{Subjects and methods}

The study was carried out in four regions of Spain including seven areas of Barcelona Province (Catalonia), Zaragoza City (Aragon), Soria Province (Castilia), Lugo Province, and the north of La Coruna Province (Galicia). Barcelona Province has a low stomach can- 
cer mortality rate, while in the other areas the rate is high (3). The overall population covered by the study was approximately 950000 .

The cases were identified and recruited from 15 hospitals in the public health system. These hospitals represented nearly all the patient care resources available in the study areas. The public health system covers more than the $90 \%$ of the Spanish population.

New cases of gastric adenocarcinoma (excluding lymphomas and other nonepithelial neoplasma) diagnosed between November 1987 and December 1989 were included, although in some areas the recruiting period was shorter. For all cases histopathological confirmation of the diagnosis was obtained. Cases occurred in residents of the study areas. Those diagnosed but deceased prior to the interview were excluded. Altogether interviews were made for 354 gastric adenocarcinoma cases ( 235 men and 119 women). The average age was 65.3 (range $31-88$ ) years. Among the interviewed, 121 were from the low risk area and 233 from the high risk area.

One referent was enrolled for each case. The referents were matched to the cases by gender, age (within three years), and area of residence. They were selected from the admission register of the same hospital as the cases. The first patient who registered after the case's admission and fulfilled the matching criteria was selected as the referent. Patients with admission diagnoses which could be associated with the risk factors under study were excluded. Such diagnoses included respiratory and digestive tract cancer, chronic respiratory diseases, diabetes, and other chronic diseases which required a special therapeutic diet.

Interviews were conducted by trained personnel at the same hospital for each matched pair of cases and referents. The interviewers were not aware of the case or referent status of the subjects. The questionnaire included a section covering occupational history for any job that lasted more than six months. Enrollment and finishing dates, working area, specific task, company name and address, and main products manufactured or services provided were recorded.

The coding of occupational history was based on the National Classification of Occupations (23), the Spanish equivalent of the International Classification of Occupations (24). It was performed by one person familiar with the classification, nomenclature, and code usage. The industrial activities were coded according to the National Classification of Economic Activities (25), a Spanish adaptation of the United Nations' Classification (26).

All jobs held for at least six months and up to one year prior to the diagnosis were analyzed by categories in the classification. A group of occupations considered "not exposed" to known or suspected carcinogens was used in order to have a reference category for the occupational analysis; this group included the Spanish equivalent of those occupations which have been previously studied in the United States and shown not to be linked to any agent with carcinogenic potential (27). In our study, the group of "not exposed" occupations included traders and salespersons and administrative and service workers according to the Spanish occupation classification. The individuals which had always worked in these occupations and those who had never worked formed the reference category.

In the analysis of each occupation as a risk factor for gastric cancer, persons who had ever worked in the occupation of interest were considered "exposed." The relative risk estimates shown in the tables compare the exposed to the specified occupation with the reference group. The individuals who had ever worked in occupations other than those from the "not exposed" group but who had never worked in the occupation being studied were not considered in the analysis.

The same procedure described for occupations was followed in the analysis by industry. The "not exposed" group for industries included commerce and financial services in the Spanish classification and those who had never worked.

In a second step, all the occupations with potential exposure to different kinds of industrial dust were identified according to an occupation-exposure linkage system (28). This matrix links different kinds of physical and chemical agents to different occupations. If there is a link between an agent and an occupation, the degree of exposure is coded further as 1 (light), 2 (moderate), 3 (heavy), or 9 (unknown intensity). In this analysis, only the occupations with the highest level of exposure (grade 3 ) were included as exposed to dust. The Spanish occupations equivalent to those in the United States linkage system with the highest level of exposure to organic dust (rubber, leather and fur, textiles, and wood) and inorganic dust (silica, metal, minerals, and chemicals) were identified. The analysis compared workers who had ever worked in these occupations with those in the reference occupations.

A univariate analysis for matched data was based on a maximum likelihood procedure to estimate relative risk (29). Miettinen's formulas for matched casereferent studies were used to calculate the confidence interval (CI) (30).

A multivariate analysis for the adjustment of variables in addition to those used in matching was based on the conditional logistic regression method (29). For the computing, a standard statistical analysis program was used (31).

Educational level and socioprofessional status were adjusted for in the multivariate analysis. Educational level was based on years of schooling completed. Socioprofessional status was based on the Spanish classification (32), which had 18 categories that were further grouped into six categories for the analysis.

Since the consumption of vegetables and fruits is one of the most important etiologic factors (protective), in addition to socioprofessional and educational level, the consumption of cooked vegetables and fresh fruits was also adjusted for in the analysis. The consump- 
tion was categorized into quartiles according to the distribution among the referents.

The analysis of occupation separately for each gender yielded similar results. Gender was, therefore, controlled for in the analysis and not presented separately.

No significant statistical difference was observed between the cases and referents on educational level and socioprofessional classification. Nonetheless socioprofessional status was adjusted for in the subsequent multivariate analysis.

The number of different jobs in which the subjects had worked over their worklife was compared between the cases and referents, and no difference was observed.

\section{Results}

Table 1 presents the job group distribution of the cases and referents, showing only groups with at least five cases who had ever worked in each occupational category. The odds ratio (OR) estimates shown were adjusted for socioprofessional status and dietary intake of vegetables and fruits. In occupations for which some evidence has suggested a risk factor for gastric cancer, we observed an increase in risk, but none of the OR estimates was statistically significant. For mining and related occupations there were 11 cases and 11 referents with an OR of 1.18 (95\% CI 0.42-3.4). A high risk was observed for wood and furniture manufacturing workers (OR 1.76, $95 \% \mathrm{CI} 0.45-6.9$ ), for construction workers (OR 1.68, $95 \%$ CI $0.85-$ 3.3 ), and for glass and ceramic workers (OR 2.2, $95 \%$ CI 0.59-8.1). The univariate OR estimates for these occupations were slightly larger and also not statistically significant. In this data set only three cases and two referents were rubber workers, and none were oil refinery workers.

Table 2 shows the distribution of cases and referents according to the types of industrial activity. For the coal and coke mining industry, 11 cases and 3 referents were observed with a high OR (11.8), which was statistically significant, but with a wide confidence interval $(95 \%$ CI 1.36-103). The unadjusted OR for this group was 9.3, and after adjustment for socioprofessional status but no adjustment for diet (consumption of vegetables and fruits) the OR was 9.9. For the metal and nonmetal mining industries, the observed risk was not increased. The estimated OR for the construction industry was lower than the estimated OR calculated for job category. For the leather industry, the OR was 2.1, but there were only five cases and three referents.

Table 3 shows the results of the exposure to different industrial dusts. For organic dusts, an increased risk was observed among rubber and leather workers. However only very few workers were in this category in the analysis. No increased risk was observed among workers exposed to metallic dust (OR $1.17,95 \% \mathrm{CI}$ $0.43-3.2$ ).

There was a relatively large number of workers exposed to silica and mineral dusts, mainly brick masons. The estimated OR was 1.80 (95 \% CI 0.90-3.6), the lower confidence limit being close to 1 .

The estimated OR for workers exposed to any of the industrial dusts studied, adjusted for socioprofessional status and diet, was 1.49 (95\% CI 0.85-2.59). The estimated OR not adjusted for diet was $1.45(95 \%$ CI 0.84-2.5).

\section{Discussion}

Different strategies were used in this analysis. The use of a group not exposed to any known carcinogen as a reference category has some advantages over the traditional methods. In the traditional method, the "ever exposed" group is compared with the "never exposed" group for each occupation. If among the never exposed there were other occupations with exposure to the same or other risk factors, the disease association could be weakened for the particular occupation studied.

The application of United States industrial exposure pattern in Spain presents some problems. The industrial processes and the substances involved could differ from one country to another, and they could be different in different periods or regions within the same country. For this reason the application of the United States dust-exposure matrix in Spain should be viewed with caution. However, having only included the highest level of exposure has the advantage of reducing the "false positives" (likelihood of being erroneously placed in the "exposed" category). On the other hand, individuals with a low level of exposure could possibly be omitted from the exposed group. However, the analysis on type of industry, which has a higher sensitivity in classification, allows an estimate of effect, including the lowest level of exposure.

Another feature of this study as compared with previous studies on occupation and gastric cancer is the adjustment for diet and socioprofessional status, the two most important confounding factors.

Previous evidence consistently suggested a possible but weak association between gastric cancer and occupations in coal mines, oil refineries, rubber industries, and industrial dust. Although substances with potential or suspected carcinogenic effect have been identified in these occupations and have therefore made this association biologically plausible, there is no identified substance which could be considered directly responsible, and there is no possible acting mechanism which has been clearly established. When an association is weak, the possibility that it is due to incomplete control of confounding factors or undetected biases has to be considered. On the other hand, 
a weak association does not automatically exclude a potential causal relation (33).

Coal dust contains silica, metal residuals, and polycyclic aromatic hydrocarbons (PAH). It has been suggested that coal particles concentrated in the lung are eliminated by the ciliary cleaning function and then swallowed with saliva, thus reaching the stomach (7). The combustion of coal products releases PAH; among them, benzo[a]pyrene is known for its carcinogenic ef- fect. Rats experimentally exposed to these products have developed tumors in the upper squamous part of the stomach (34). Alderson (35), who simultaneously analyzed eight different studies on the mining industry, estimated a combined relative risk of 1.66 . However, there are other studies that showed no increase in risk $(36,37)$. Others have questioned whether the increased risk could be directly related to occupation or could be a result of extraneous factors such as the

Table 1. Number of cases and referents who had ever worked in each large occupational groups and the odds ratio (OR) adjusted for professional status and diet. ${ }^{a}(95 \% \mathrm{GI}=95 \%$ confidence interval)

\begin{tabular}{|c|c|c|c|c|}
\hline \multirow{2}{*}{ Occupational classification ${ }^{b}$} & \multicolumn{2}{|c|}{ Ever worked } & \multirow{2}{*}{$\mathrm{OR}^{\mathrm{c}}$} & \multirow{2}{*}{$95 \% \mathrm{Cl}$} \\
\hline & Cases & Referents & & \\
\hline Sales persons, clerical workers service workers $(30 / 59)$ & 79 & 83 & 1.00 & $\cdot$ \\
\hline Professionals $(01 / 19)$ & 9 & 11 & 1.13 & $0.41-3.1$ \\
\hline Managers (20/21) & 3 & 6 & 0.47 & $0.10-2.1$ \\
\hline Agriculture, cattle (60/62) & 164 & 169 & 1.05 & $0.63-1.74$ \\
\hline Forestry (63) & 7 & 7 & 1.03 & $0.30-3.6$ \\
\hline Chiefs $(70)$ & 6 & 7 & 0.98 & $0.29-3.4$ \\
\hline Miners and related $(71)$ & 11 & 11 & 1.18 & $0.42-3.4$ \\
\hline Metal processor (72) & 7 & 10 & 0.77 & $0.26-2.3$ \\
\hline Wood, paper production (73) & 5 & 11 & 0.52 & $0.16-1.66$ \\
\hline Textile workers (75) & 33 & 29 & 1.24 & $0.62-2.5$ \\
\hline Food and beverages (75) & 15 & 14 & 1.28 & $0.52-3.1$ \\
\hline Dressmaker (79) & 12 & 11 & 1.14 & $0.45-2.9$ \\
\hline Furniture, wood manufacturers (81) & 6 & 4 & 1.76 & $0.45-6.9$ \\
\hline Toolmakers $(83)$ & 12 & 10 & 1.36 & $0.48-3.8$ \\
\hline Mechanics (84) & 8 & 14 & 0.56 & $0.20-1.54$ \\
\hline Glass, ceramics (89) & 8 & 4 & 2.2 & $0.59-8.1$ \\
\hline Construction (95) & 50 & 38 & 1.68 & $0.85-3.3$ \\
\hline Load, unload (97) & 20 & 21 & 1.07 & $0.48-2.4$ \\
\hline Transport (98) & 18 & 18 & 1.23 & $0.53-2.8$ \\
\hline Not elsewhere classified (99) & 31 & 30 & 1.04 & $0.50-2.2$ \\
\hline
\end{tabular}

a Reference category = sales persons + services workers + clerical workers + never worked.

b Code of the National Classification of Occupations (23) in parentheses.

c Conditional logistic regression analysis.

Table 2. Number of cases and referents exposed in large economic activity groups (industry) and the odds ratio (OR) adjusted for professional status and diet. ${ }^{a}(95 \% \mathrm{Cl}=95 \%$ confidence interval $)$

\begin{tabular}{|c|c|c|c|c|}
\hline \multirow{2}{*}{ Industrial group ${ }^{b}$} & \multicolumn{2}{|c|}{ Ever worked } & \multirow{2}{*}{$\mathrm{OR}^{\mathrm{c}}$} & \multirow{2}{*}{$95 \% \mathrm{Cl}$} \\
\hline & Cases & Referents & & \\
\hline Sales, financial services $(61 / 64,81 / 99)$ & 74 & 75 & 1 & $\cdot$ \\
\hline Agriculture (01) & 147 & 140 & 1.08 & $0.64-1.83$ \\
\hline Cattle (02) & 41 & 45 & 0.91 & $0.46-1.78$ \\
\hline Coal and coke mining (11) & 11 & 3 & 11.8 & $1.36-103$ \\
\hline Production and distribution of gas or electricity (15) & 2 & 6 & 0.36 & $0.07-1.95$ \\
\hline Metal mining (21) & 3 & 3 & 1.14 & $0.21-6.2$ \\
\hline Nonmetal mineral mining (23) & 1 & 8 & 0.14 & $0.02-1.16$ \\
\hline Nonmetal mineral industry (24) & 11 & 11 & 0.97 & $0.36-2.6$ \\
\hline Chemical industry (25) & 4 & 5 & 0.81 & $0.20-3.3$ \\
\hline Metallic manufacturing (31) & 22 & 23 & 0.97 & $0.45-2.1$ \\
\hline Machinery manufacturing (32) & 3 & 4 & 1.02 & $0.20-5.2$ \\
\hline Electric manufacturing (34) & 1 & 6 & 0.14 & $0.02-1.31$ \\
\hline Food and beverages industry (41/42) & 20 & 23 & 0.95 & $0.43-2.1$ \\
\hline Textile industry (43) & 44 & 38 & 1.17 & $0.59-2.3$ \\
\hline Leather industry (44) & 5 & 3 & 2.1 & $0.46-10$ \\
\hline Shoes and clothing industry (45) & 14 & 12 & 1.06 & $0.42-2.7$ \\
\hline Wood and cork furniture (46) & 17 & 20 & 0.89 & $0.39-2.1$ \\
\hline Paper and graphics industry (47) & 7 & 7 & 0.97 & $0.28-3.4$ \\
\hline Rubber and plastic industry (48) & 3 & 3 & 1.02 & $0.19-5.5$ \\
\hline Construction industry $(50)$ & 65 & 57 & 1.29 & $0.66-2.5$ \\
\hline Restaurants, hotels $(65 / 66)$ & 13 & 11 & 1.24 & $0.45-3.4$ \\
\hline Repairs (67) & 7 & 9 & 0.79 & $0.27-2.3$ \\
\hline Transport $(71 / 75)$ & 27 & 22 & 0.89 & $0.40-2.0$ \\
\hline
\end{tabular}

a Reference category = sales + financial services + never worked.

b Code of the National Classification of Economic Activities (25) in parentheses.

$c$ Conditional logistic regression analysis. 
Table 3. Cases and referents by dust exposure group and the odds ratio (OR) adjusted for professional status and diet. ${ }^{a}(95 \%$ $\mathrm{Cl}=$ confidence interval)

\begin{tabular}{|c|c|c|c|c|}
\hline \multirow{2}{*}{ Dust exposure group ${ }^{b}$} & \multicolumn{2}{|c|}{ Exposed } & \multirow{2}{*}{$\mathrm{OR}^{\mathrm{c}}$} & \multirow{2}{*}{$95 \% \mathrm{Cl}$} \\
\hline & Cases & Referents & & \\
\hline \multicolumn{5}{|l|}{$\begin{array}{l}\text { Rubber production (901) } \\
\text { Tire production (902) }\end{array}$} \\
\hline \multicolumn{5}{|l|}{$\begin{array}{l}\text { Shoe production (801) } \\
\text { Shoe repair (802) } \\
\text { Other leather workers (803) }\end{array}$} \\
\hline \multicolumn{5}{|l|}{$\begin{array}{l}\text { Fiber preparation (751) } \\
\text { Spinning workers (752) } \\
\text { Weaving (753-755) }\end{array}$} \\
\hline \multicolumn{5}{|l|}{$\begin{array}{l}\text { Wood production (731) } \\
\text { Sawyer (732-733) } \\
\text { Wood processing (812) } \\
\text { Furnitures (819) } \\
\text { Carpenter }(954)\end{array}$} \\
\hline $\begin{array}{l}\text { Silica and mineral } \\
\text { Brick mason (951-952) } \\
\text { Stone processing }(820) \\
\text { Glass production (891) } \\
\text { Ceramic production (892) } \\
\text { Glass and ceramics processing (893-899) } \\
\text { Nonmetal minerals (943) }\end{array}$ & $\begin{array}{l}49 \\
41\end{array}$ & $\begin{array}{l}35 \\
31\end{array}$ & $\begin{array}{l}1.80 \\
1.69\end{array}$ & $\begin{array}{l}0.90-3.59 \\
0.82-3.46\end{array}$ \\
\hline \multicolumn{5}{|l|}{$\begin{array}{l}\text { Blacksmiths }(831) \\
\text { Polisher }(835) \\
\text { Turner }(835-839) \\
\text { Nonmetal minerals (943) }\end{array}$} \\
\hline $\begin{array}{l}\text { Chemical } \\
\text { Painters }(931-939)\end{array}$ & 2 & 3 & 0.39 & $0.04-3.93$ \\
\hline Mining (711-712) & 10 & 11 & 0.90 & $0.36-2.28$ \\
\hline \multicolumn{5}{|l|}{ Total } \\
\hline $\begin{array}{l}\text { Reference category } \\
\text { Exposed to any dust job } \\
\text { Any other jobs }\end{array}$ & $\begin{array}{r}79 \\
108 \\
167\end{array}$ & $\begin{array}{r}83 \\
87 \\
184\end{array}$ & $\begin{array}{l}1.0 \\
1.49 \\
0.99\end{array}$ & $\begin{array}{l}0.86-2.59 \\
0.61-1.62\end{array}$ \\
\hline
\end{tabular}

a Reference category = sales + services workers + clerical workers + never worked.

b Code of the National Classification of Occupations (23) in parentheses.

c Conditional logistic regression analysis.

absence or insufficient adjustment for social class and dietary habits (6). Our results show that diet is apparently not a confounding factor in this data set.

The two case-referent studies with negative results have potential bias which could have led to an underestimation of the risk. In the study of Weimberg et al (36), nondifferential information bias cannot be eliminated since the study was based on deceased cases and referents and the information on occupation was collected indirectly from relatives and by phone. In the study of Swaen et al (37) selection bias could have existed. Referents were recruited from hospitals in a mining area without any admission or exclusion criteria, and the fact that $22 \%$ of the referents were miners could indicate an overrepresentation of exposed subjects in the reference sample.

Our results support the possible presence of a causal association between stomach cancer and coal exposure. If risk is analyzed with all types of mining (table 1), there is no increased risk, but, if it is analyzed according to the type of mining (table 2), a high risk is associated with coal mining.

In this study the magnitude of the OR (11.8) for coal exposure is considerably higher than previously reported (between 1.5 and 1.8). The OR has a wide confidence interval and could be due to the small number of workers within this job category in our study population.

A detailed analysis of the occupational history of the exposed cases (table 4) showed that most of them had had occupations with long exposure to coal and that the initial exposure started sometime between 1940 and 1973. Theoretically, these admission dates are compatible with a long latency period, as has been suggested in another study (9). Among the 11 cases, one was an administrative worker who had worked 29 years in mining. All of them had worked in coal mines in the Barcelona Province. 
Table 4. List of cases and referents who had ever worked in the coal mining industry.

\begin{tabular}{|c|c|c|c|c|}
\hline $\begin{array}{l}\text { Case/referent } \\
\text { status }\end{array}$ & Industry & $J b^{a}$ & $\begin{array}{c}\text { Year } \\
\text { (start/end) }\end{array}$ & $\begin{array}{c}\text { Age at } \\
\text { diagnosis } \\
\text { (years) }\end{array}$ \\
\hline Case 1 & Coal mining & Hopper driver $(979.40)$ & $1965 / 1970$ & 58 \\
\hline Case 2 & Coal mining & Miner $(711.05)$ & $1940 / 1944$ & 69 \\
\hline Case 3 & Coal mining & Stint worker (999.10) & $1942 / 1988$ & 71 \\
\hline Case 4 & Coal mining & Load hopper (973.50) & $1955 / 1964$ & 66 \\
\hline Case 5 & Coal mining & Load hopper (973.50) & $1945 / 1947$ & 54 \\
\hline Case 6 & Coal mining & Miner (711.90) & $1941 / 1942$ & 74 \\
\hline Case 7 & Coal mining & Miner (711.05) & $1971 / 1988$ & 42 \\
\hline Case 8 & Coal mining & Miner $(711.90)$ & $1951 / 1953$ & 63 \\
\hline Case 9 & Coal mining & Store worker (391.40) & $1948 / 1986$ & 58 \\
\hline Case 10 & Coal mining & Clerk $(393.10)$ & $1944 / 1973$ & 57 \\
\hline Case 11 & Coal mining & Refining $(721 / 70)$ & $1973 / 1988$ & 59 \\
\hline Referent 1 & Coal mining & Miner (711.05) & $1942 / 1947$ & 57 \\
\hline Referent 2 & $\begin{array}{l}\text { Coal mining } \\
\text { Coal mining }\end{array}$ & $\begin{array}{l}\text { Mechanic }(849.35) \\
\text { Chief }(700.20)\end{array}$ & $\begin{array}{l}1968 / 1976 \\
1976 / 1988\end{array}$ & 41 \\
\hline Referent 3 & $\begin{array}{l}\text { Coal mining } \\
\text { Coal mining }\end{array}$ & $\begin{array}{l}\text { Cart driver }(986.90) \\
\text { Miner }(711.05)\end{array}$ & $\begin{array}{l}1950 / 1965 \\
1965 / 1975\end{array}$ & 64 \\
\hline
\end{tabular}

a Code of the National Classification of Occupations (23) in parentheses.

For the rubber industry, Alderson (35) estimated, in a simultaneous analysis of eight prospective studies, a pooled relative risk of 1.23 (95\% CI $1.1-1.3)$, and the association was considered likely to be causal. In rubber manufacturing, exposure to several substances is possible, for example, accelerators, antioxidants, solvents, oils, fumes, and talc and other dusts (10), but none of them have been identified as responsible for the elevated risk.

For oil refinery workers, one of several prospective studies has shown an increased risk of stomach cancer (38). The scientific evidence available on the carcinogenic effect of working in refineries and oil derivative industries on humans is considered inadequate even though evidence from animal experimentation is judged to be sufficient (39). Our study did not show an increased risk for occupations related to the rubber industry, although this result could be due to the fact that the number of exposed cases and referents in our series was very small. Our data did not include any subject who had ever worked in an oil refinery. It is known that one of the limitations of a case-referent study on occupational factors is that it can only evaluate the risk associated with occupations present in the geographic areas of the study. These industries are not prevalent in our study areas.

A case-referent study carried out in Spain in the central region of Castilia on the basis of death certificates (40) showed an increased risk of stomach cancer among farmers (OR 1.41, $95 \%$ CI 1.23-1.61). In agriculture, exposure to fertilizers and pesticides which could be a precursor of nitrosamines is possible (41). In our study agriculture and cattle raising had the largest number of cases and referents exposed, but an increased risk was not observed.
For industrial dust, an elevated, but not statistically significant risk was found for occupations exposed to silica and other mineral dusts. For organic dust, an increased risk was observed in occupations related to rubber and leather. However, the number of cases was small, and the association was not statistically significant.

A study from California (16) showed that the highest risk of stomach cancer coincided with mineral dusts in jobs related to construction. Wright et al (16) have reported that the higher risk was for tumors located in the antrum or pylorus. In our study, however, the greatest risk was observed for the body and the subcardial area.

For workers exposed to any type of industrial dusts, the relative risk was $1.49(95 \% \mathrm{CI} 0.86-2.1)$, a value that is similar to that calculated by Wright (OR 1.3, $95 \%$ CI 1.2-1.4). It needs to be pointed out that this study analyzed only the occupation at the time of diagnosis. This limitation could lead to an underestimation of the magnitude of the effect. However, Wright's study had a high power because it included more than 1300 cases of gastric adenocarcinoma.

In conclusion, our study provided some evidence supporting the possibility of a causal association between gastric adenocarcinoma and exposure to coal in the mining industry and exposure to silica dust. The elevated OR estimates were observed even after control for socioprofessional status and diet, the two factors that have been suggested as confounding factors.

\section{Acknowledgments}

This study received financial support from the Health Research Fund (FIS) of the Spanish Ministry of Health 
(Financial Aid for Research exp 87/1703 and exp 89/0018) and the International Agency for Research on Cancer (Collaborative Research Agreement AEP/ 88/02).

The authors are grateful to Mr C Mas for his important office work, and Mr M Torrent for his valued assistance in developing and analyzing the data. We wish to express our gratitude to Professor D Trichopoulous for his collaboration in the analysis and to the oncologists, digestologists, and pathologists who collaborated in the study: A Badia, A Serrano, X Balanzó, R Diloy (Hospital de Mataró); T Cardona, A Verdaguer, A Garcia (Clínica Aliança Mataró); LL Cirera, T Ribas, X Garau, J M Viver (Mutua de Terrassa); A Arcusa, R Audell, J Armengol, J Verge (Hospital de Terrassa); E Saigí, M Barnet, C Padrós, R Pujol (Hospital General de Granollers); E Batiste-Alentorn, F Antonell, J Brugués (Hospital General de Vic); A Tres, J Ortego, V Tejedo, C Aznar, R Sainz (Hospital Clínico, Zaragoza); G Garcia, P Solanilla (Hospital M Servet Zaragoza); M Rey, F Segura, E Brullet (Hospital de Sabadell); J M Badal, M Aliart, Badosa (Hospital de St. Andreu de Manresa); X Puig (Centre Hospitalari de Manresa); J Sorribes, F Porta (Hospital Sant Joan de Deu de Manresa); M Boleda, D Moreo (Hospital de Sant Camil); E Casariego (Hospital General de Lugo); D Vázquez (Hospital Juan Canalejo, La Coruña); JC Alvarez (Hospital del Ferrol); JM Ruiz, Rodríguez, V del Villar, ML Muñoz (Hospital del INSALUD, Soria).

\section{References}

1. Parkin D, Läärä E, Muir C. Estimates of the worldwide frequency of sixteen major cancers in 1980 . Int $\mathrm{J}$ cancer 1988;41:184-97.

2. Ministerio de Economia, Instituto Nacional de Estadística. Movimiento natural de la población española 1985. Madrid: Ministerio de Economia, Instituto $\mathrm{Na}-$ cional de Estadística, 1989.

3. López Abente G, Escolar A, Errezola M. Atlas del cáncer en España. Vitoria 1984.

4. Howson CP, Hiyama T, Wynder EL. The decline of gastric cancer: epidemiology of an unplanned triumph. Epidemiol Rev 1986;8:1-27.

5. Correa P, Haenszel W, Cuello C, et al. A model for gastric cancer epidemiology. Lancet $1975 ; 2: 58-60$.

6. Stocks $P$. On the death rates from cancer of the stomach and respiratory diseases in 1949 to 1953 among coal miners and other male residents in counties of England and Wales. Br J Cancer 1962;16:592-8.

7. Ames RG. Gastric cancer and coal mine dust exposure: a case-control study. Cancer 1983;52:1346-50.

8. Creagan ET, Hoover RN, Fraumeni JF Jr. Mortality from stomach cancer in coal mining regions. Arch Environ Health 1974;28:28-30.

9. Rockette HE. Cause specific mortality of coal miners. J Occup Med 1977;19:798.

10. Delzell W, Monson RR. Mortality among rubber workers: V. processing workers. J Occup Med 1982;24: 539-45.

11. Peters JM, Monson RR, Burgess WA, Fine LJ. Occupational disease in the rubber industry. Environ Health Perspect $1976 ; 17: 31-4$

12. Sorahan T, Parkes HG, Veys CA, Waterhouse JAH.
Cancer mortality in the British rubber industry. $\mathrm{Br} \mathrm{J}$ Ind Med 1986;43:363-73.

13. Hanis NM, Stavraky KM, Fowler JL. Cancer mortality in oil refinery workers. J Occup Med 1979;21:167.

14. Rushton L, Alderson MR. An epidemiological survey of eight oil refineries in Britain. Br J Ind Med 1981; $38: 225-34$.

15. Thomas TL, Waxweiler RJ, Moure-Eraso R, Itaya S, Fraumeni JF Jr. Mortality patterns among workers in three Texas oil refineries. J Occup Med. 1982;24:135.

16. Wright WE, Bernstein L, Peters JM, Garabrant DH, Mack TM. Adenocarcinoma of the stomach and exposure to occupational dust. Am J Epidemiol 1988; 128:64-73.

17. McDowall ME. A mortality study of cement workers. Br J Ind Med 1984;41:179-82.

18. Selikoff IJ, Hammond EC, Seidman H. Latency of asbestos disease among insulation workers in the United States and Canada. Cancer 1980:46:2736-40.

19. Järvholm B, Thiringer $G$, Axelson O. Cancer morbidity among polishers. Br J Ind Med 1982;39:196-97.

20. Wegman DH, Eisen EA. Causes of death among employees of a synthetic abrasive product manufacturing company. J Occup Med 1981;23:748-54.

21. Sparks PJ, Wegman DH. Cause of death among jewelry workers. J Occup Med 1980;22:733-6.

22. Hogstedt C, Aringer L, Gustavsson A. Epidemiologic support for ethylene oxide as a cancer-causing agent. JAMA 1986;255:1575-8.

23. Ministerio de Economia y Comercio. Clasificación nacional de ocupaciones: revisión 1979. Madrid: Ministerio de Economia y Comercio 1980.

24. International Labour Office (ILO). International standard classification of occupations, revised edition, 1968. Geneva: ILO, 1969

25. Ministerio de Economia, Instituto Nacional de Estadísticas. Clasificación nacional de actividades económicas: año 1974. Segunda Edición. Madrid: Ministerio de Economia, Instituto Nacional de Estadísticas 1984

26. United Nations. Statistical papers: series $M$, no 4 , rev 2. New York, NY: United Nations, 1968.

27. Hsieh CC, Walker AM, Hoar SK. Grouping occupations according to carcinogenic potential: occupation clusters from an exposure linkage system. Am J Epidemiol 1983;117:575-89.

28. Hoar SK, Morrison AS, Cole P, et al. An occupation and exposure linkage system for the study of occupational carcinogenesis. J Occup Med 1980;22:722-26.

29. Breslow NE, Day NE. Statistical methods in cancer research; vol 1 (The analysis of case-control studies). Lyon: International Agency for Research on Cancer, 1980. (Scientific publication; no 32.)

30. Miettinen OS. Estimation of relative risk from individually matched series. Biometrics 1970;26:7585.

31. Epicenter Software. Epilog microcomputer epidemiology statistics package. Version 3. Pasadena, CA: Epicenter Software, 1988.

32. Ministerio de Economia, Instituto Nacional de Estadistica. Anuario estadístico de españa. Madrid: Ministerio de Economia, Instituto Nacional de Estadística, 1978.

33. Rothman K. Modern epidemiology. Boston, MA: Little, Brown and Company, 1986

34. Triolo AJ, Aponte GE, Herr DL. Induction of aryl hydrocarbon hydroxylase and forestomach tumors by benzo(a)pyrene. Cancer Res 1977;37:3018-21.

35. Alderson M. Occupational cancer. London: Butterworths, 1986.

36. Weimberg GB, Kuller LH, Stehr PA. A case-control study of stomach cancer in a coal mining region of Pennsylvania. Cancer 1985;56:703-13.

37. Swaen GMH, Maerdts CWH, Sturmans F, Slangen JJM, Knipschild P. Gastric cancer in coal miners: a casecontrol study in a coal mining area. Br J Ind Med 1985; 42:627-30. 
38. Wen CP, Tsal SP, McClellan WA, Gibson RL. Longterm mortality study of oil refinery workers: I. mortality of hourly and salaried workers. Am J Epidemiol 1983;118:526-42.

39. International Agency for Research on Cancer (IARC). Occupational exposure in petroleum refining. Lyon: IARC, 1989. (IARC monographs on the evaluation of carcinogenic risks to humans; no 45 .)

40. López-abente G. Cáncer en agricultores: mortalidad proporcional y estudios caso-control concertificados de defunción [Doctoral dissertation]. Madrid: Universidad Autónoma de Madrid, 1990.

41. Blair A, Malker H, Cantor KP, Burmeister L, Wiklund K. Cancer among farmers: a review. Scand J Work Environ Health 1985;11:397—407.

Received for publication: 22 November 1990 